\title{
Mechanism for the Decision of Ovarian Surface Epithelial Stem Cells to Undergo Neo-Oogenesis or Ovarian Tumorigenesis
}

\author{
Jiao Xu $u^{a, b, c}$ Tuochen Zhenga, ${ }^{a, b, c}$ Wenli Hong ${ }^{d}$ Haifeng Ye $e^{a, b}$ Chuan Hu, \\ Yuehui Zhenga,b

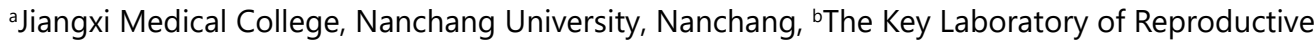 \\ Physiology and Pathology of Jiangxi Provincial, Nanchang, 'School of the 1st Clinical Medical Sciences, \\ Jiangxi Medical College, Nanchang University, Nanchang, ${ }^{\mathrm{d} T h e}$ Zhuhai Campus of the Zunyi Medical \\ College, Zhuhai, China
}

\section{Key Words}

Ovarian surface epithelium • Ovarian stem cells • Ovarian cancer • Premature ovarian failure

\begin{abstract}
The ovary is surrounded by a whitish layer of mesodermally derived ovarian surface epithelium (OSE) that lines the intraembryonic celom and comprises simple squamous to cuboidal to low pseudostratified columnar epithelial cells. Its integrity is maintained by simple desmosomes, incomplete tight junctions, several integrins and cadherins. Recent research has found that ovarian stem cells (OSCs) exist within the OSE and may be responsible for both neo-oogenesis and ovarian cancer during adult life. The factors determining whether OSCs undergo neooogenesis or ovarian cancer are of great interest to researchers and clinicians. Accumulating evidence suggests the mechanism for the decision of ovarian surface epithelial stem cells to undergo either neo-oogenesis or ovarian cancer transformation may comprise both internal and external factors. Here, we review recent progress on how the internal factors, including genes, signaling pathways and IncRNA: OSE stem cells mediate the development and progression of ovarian cancer through various genes such as p53, KRAS, BRAF, and PTEN, and mutations in PIK3CA, and through various signaling pathways, including TGF-B pathway, Wnt signaling pathway, Notch signaling pathway, NF-kB signal transducer and transcriptional activator 3 (STAT3) pathway and Hedghog $(\mathrm{HH})$ pathway. A series of expressions of IncRNA have changed in epithelial ovarian cancer tissues and cell lines compared to normal ovarian tissues and cell lines. As well as external factors, including incessant ovulation, gonadotropin and chronicinflammation: Frequent ovulation, without long-term dormancy, increases the risk of illness, because repeated rupture and repair at the ovulation site provides an opportunity for the accumulation of genetic aberrations; FSH affects all aspects of ovarian cancer metastasis, such as inhibition of apoptosis, through Induction of increased expression of VEGFA (VEGF) to support tumor growth, promote vascular growth, and possibly alter certain J. Xu and T. Zheng contributed equally to this work.

\begin{tabular}{ll}
\hline Chuan Hu & Jiangxi Medical College \\
and Yuehui Zheng & Room 103, Administration Building, Nanchang University, Nanchang, Jiangxi 330031 (China) \\
& E-Mail 160920633@qq.com; yuehuizheng@163.com
\end{tabular}
\end{abstract}




\section{Cellular Physiology Cell Physiol Biochem 2018;50:214-232 \\ \begin{tabular}{ll|l} 
and Biochemistry & $\begin{array}{l}\text { DOI: 10.1159/000494001 } \\
\text { Published onlıne: 4 October } 2018\end{array}$ & $\begin{array}{l}\text { (c) } 2018 \text { The Author(s). Published by S. Karger AG, Basel } \\
\text { www.karger.com/cpb }\end{array}$ \\
\hline Xu et al: Mechanism for the Decision of OSESCs to Undergo Neo-
\end{tabular} \\ Tumorigenesis}

oncogenic pathways, thereby promoting proliferation and invasive phenotypic inflammation contributes to tumorigenesis, which help determine whether OSCs undergo neo-oogenesis or ovarian tumorigenesis. Understanding this issue is critical for developing novel strategies for premature ovarian failure and ovarian cancer prevention and therapy.

(C) 2018 The Author(s)

Published by S. Karger AG, Basel

\section{Introduction}

The function of healthy OSEs is the regeneration and repeated proliferation of cells after ovulation during the reproductive cycle. Due to its paucity of significant functions, the OSE has received less attention compared to other components of ovarian tissue. Over the past few decades, however, the field of reproductive biology has significantly progressed due to the finding that the OSE contains ovarian stem cells (OSCs). The role of OSCs in the pathogenesis of epithelial ovarian carcinoma is well established; however, their role in human oogenesis has remained controversial [1-3]. Recently, OSCs isolated from the ovaries of 5-day-old and adult mice using immunomagnetic sorting for DEAD (Asp-Glu-Ala-Asp) box polypeptide 4 (DDX4) were cultured for more than 15 months or for 6 months, respectively, and exhibited proliferative capacity and a normal karyotype. Furthermore, the cell line produced fertile offspring after transplantation into ovaries. Subsequently, OSC capabilities were demonstrated in rat and human [4-9]. Hence, researchers have come to believe the OSE not only regulates the pathogenesis of epithelial ovarian carcinoma but also plays a role in mammalian neo-oogenesis. The mechanism for whether OSCs participate in neooogenesis or ovarian cancer conversion have not been intensively studied. In this review, we summarize the embryonic development and anatomic structure of ovarian surface epithelium, the function of ovarian surface epithelial stem cells in neo-oogenesis and ovarian cancer conversion and current knowledge about how internal and external factors determine OSC fate toward neo-oogenesis or ovarian cancer conversion.

\section{Embryonic Development and Anatomic Structure of Ovarian Surface Epithelium}

Early in development, the future OSE forms part of the coelomic epithelium, which is the mesodermally derived epithelial lining of the intraembryonic coelom. It overlies the presumptive gonadal area and, after proliferation and differentiation, gives rise to part of the gonadal blastoma. Starting at approximately 10 weeks of development and continuing to the fifth month of human gestation, the fetal OSE changes from a flat-to-cuboidal simple epithelium with a fragmentary basement membrane to a multistratified, papillary epithelium on a well-defined basement membrane, but it reverts to a monolayer by term. It has been postulated that the growth signals for the fetal OSE to include intragonadal steroid hormones because morphological evidence of steroid differentiation of ovarian stromal cells temporally parallels enhanced OSE growth and morphogenesis [10,11].

There are differences between the OSE and the extraovarian mesothelium during fetal development. One of the most interesting differences between these two components of the pelvic mesothelium is the expression of CA125, a cell surface glycoprotein of unknown function, which, in adults, is both an epithelial differentiation marker and a tumor marker for ovarian and Mullerian duct-derived neoplasms [12] . Fetal OSE is also a likely developmental source for ovarian granulosa cells. It is still a point of controversy whether granulosa cells are embryonically derived from the OSE, from mesonephric tubules via the intraovarian rete, or from both and to what degree these origins vary among species. There is good evidence, however, that in the human, OSE is the source of at least part of the granulosa cells. Furthermore, this distinction only becomes important in late stages of development because the OSE and the intraovarian rete have a common origin in the coelomic epithelium that overlies the urogenital ridges [13-18]. In addition to its likely role as a progenitor of granulosa cells via the fetal OSE, the coelomic epithelium in the vicinity of the presumptive 


\section{Cellular Physiology Cell Physiol Biochem 2018;50:214-232

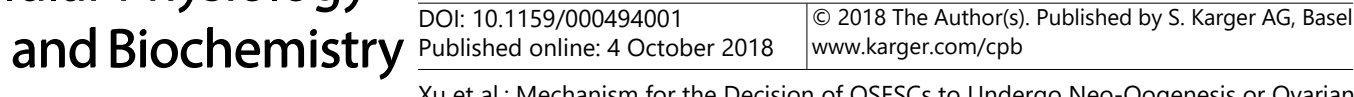 \\ Tumorigenesis}

gonads invaginates, giving rise to the Mullerian (paramesonephric) ducts, i.e., the primordial for the epithelia of the oviduct, endometrium, and endocervix. Thus, the coelomic epithelium in and near the gonadal area represents an embryonic field with the capacity to differentiate along many different pathways. The relevance of this close developmental relationship between the Mullerian epithelia and the OSE to ovarian epithelial carcinogenesis is becoming apparent [11].

In the mature woman, the OSE is an inconspicuous, monolayer squamous-to-cuboidal epithelium. It is characterized by keratin types $7,8,18$, and 19 , which represent the keratin complement typical forsimple epithelia. It expresses mucin antigen MUC1,17b-hydroxysteroid dehydrogenase, and cilia, distinguishing it from extraovarian mesothelium, apical microvilli, and basal lamina. Intercellular contact and epithelial integrity of the OSE are maintained by simple desmosomes, incomplete tight junctions, several integrins and cadherins [1922]. Surface cells are continuous at the hilum with the mesothelium of the ovarian ligament (mesovarium) and peritoneum. Preferential outgrowth of a preovulatory follicle brings it into close apposition with the ovarian surface. In most mammals, the entire surface of the ovary, other than those regions disrupted by ovulation, is covered by epithelial cells. The OSE is separated from the ovarian stroma by the tunica albuginea. This structure is thinner and less resilient than the tunica albuginea in the testis, but likely provides a partial barrier to the diffusion of bioactive agents between the ovarian stroma and OSE.

The OSE differs from all other epithelia in its tenuous attachment to its basement membrane, from which it is easily detached by mechanical means [11]. Until recently, the resulting loss of OSE in surgical specimens was responsible for the widely held opinion that the OSE is frequently absent in the ovaries of older women. Whether this loose attachment has any physiological consequences is not known. With age, the human ovary assumes increasingly irregular contours and forms OSE-lined surface invaginations (clefts) and epithelial inclusion cysts in the ovarian cortex. It has been suggested that the squamous and cuboidal forms of OSE cells on the ovarian surface represent cell groups that, respectively, have or have not undergone postovulatory proliferation [23]. In addition, OSE cells tend to assume columnar shapes, especially within clefts and inclusion cysts. Whether these shape changes are the result of crowding or whether they reflect genetically determined metaplastic changes is not always clear, but they may be derived by either process. The importance of surface invaginations and inclusion cysts lies in the propensity of the OSE in these regions to undergo metaplastic changes, i.e., to take on phenotypic characteristics of Mullerian (usually tubal) epithelium, which include columnar cell shapes and several markers found in ovarian neoplasms, including CA125 and E-cadherin [24-26]. It has been suggested that the inclusion cysts form from OSE fragments that are trapped in, or near, ruptured follicles at the time of ovulation $[27,28]$.

\section{Ovarian surface epithelial stem cells can undergo neo-oogenesis or ovarian cancer conversion (transformation)}

\section{Ovarian surface epithelial stem cells and ovarian cancer}

Ovarian cancer is the fifth most frequent cancer in women, after cancers of the breast, colorectum, lung and endometrium. Ovarian cancer is the most lethal gynecologic malignancy and carries a 1-in-70 lifetime risk. Diagnoses of epithelial ovarian cancer increase with age, and the average age at initial presentation is 61. Most cases are sporadic, with $5-10 \%$ being familial. Efforts at improving early detection and developing new therapeutic approaches to reduce mortality have been largely unsuccessful because the origin and pathogenesis of epithelial ovarian cancer remain poorly understood. Studies have found almost $90 \%$ of ovarian cancer originates from the ovarian surface epithelium (mesothelium) that invaginates into the underlying stroma resulting in inclusion cysts that eventually undergo malignant transformation [25-27, 29] . As a result, Wright et al. [30] think that if the OSE is removed, the risk for developing ovarian cancer can be greatly reduced, 


\section{Cellular Physiology Cell Physiol Biochem 2018;50:214-232 \begin{tabular}{ll|l} 
DOl: 10.1159/000494001 & O 2018 The Author(s). Published by S. Karger AG, Basel \\
wwww.karger.com/cpb
\end{tabular}

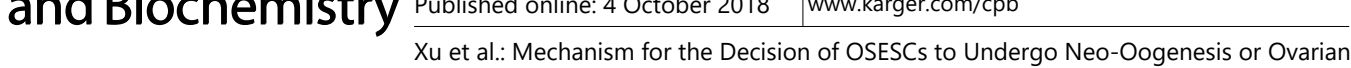 \\ Tumorigenesis}

but whether removing the OSE will affect ovarian function is still unknown. To address this question, they used a rhesus monkey model to examine ovarian function. The results show that the menstrual cycle, estrogen and progesterone levels, steroid production, and follicular development were normal after resection of OSE. A subsequent study by Wright et al. [31] used a rhesus monkey model to extend observation time to 6 months and 12 months after removal of the OSE and obtained similar results. This study provides a new strategy for preventing ovarian cancer. However, because the study extends only one year after removal of the OSE, the longer-term effects on the ovaries are still unknown, including fertility status. As such, ovarian cancer-specific mechanisms and functions of the OSE are still unclear, with much remaining to be further studied.

The cells of origin for ovarian cancer and the mechanism by which cancer develops have been long debated. The aggressive nature of ovarian cancer and the unsuccessful treatment of women with this deadly disease have recently been explained by the theory of cancer stem cells (CSCs). It has been reported that ovarian carcinogenesis and progression of disease are associated with the epithelial-mesenchymal transition (EMT). EMT, a physiological cell process that occurs during embryonic development and later in life during regeneration, could, when induced in a pathological condition, generate CSC-like cells. Virant-Klun analyzed ovarian tissue sections of 20 women with high grade serous ovarian carcinoma using immunohistochemistry for vimentin and pluripotency-related markers and observed a population of small NANOG-positive cells with diameters of up to $5 \mu \mathrm{m}$ and nuclei that filled almost the entire cell volume among epithelial cells of the ovarian surface epithelium. These small NANOG-positive cells were, in some cases, concentrated in regions with morphologically altered epithelial cells. Within these regions, a population of larger, round cells with diameters of 10-15 $\mu \mathrm{m}$, large nuclei, and positive staining for vimentin, NANOG and other markers of pluripotency, were released from the surface epithelium. These cells are proposed to be CSCs, possibly originating from small stem cells among the epithelial cells. They form typical cell clusters, invade the tissue by changing their round shape into a mesenchymal-like phenotype, and contribute to the manifestation of ovarian cancer [32] (Fig.1). Recently, Flesken-Nikitinit used serial sphere generation and longterm lineage tracing assays to show that cells of the hilum OSE are slowly cycling and express the stem/progenitor cell markers ALDH1, Lgr5, Lef1, CD133, and CK6b. These cells display longterm stem cell properties ex vivo and in vivo. Importantly, hilum cells exhibit increased transformation potential after inactivation of tumor suppressor genes Trp53 and $\mathrm{Rb} 1$, whose pathways are frequently altered in the most aggressive and common type of human ovarian cancer, highgrade serous adenocarcinoma.

Fig. 1. Different populations of vimentin and NANOG-positive (brown) putative stem cells in ovarian sections of women with serous ovarian cancer (in situ): small VSELlike stem cells with diameters of about $5 \mu \mathrm{m}$ among epithelial cells in the ovarian surface epithelium and bigger round stem cells with diameters of 10$15 \mu \mathrm{m}$ separating from the layer of epithelial cells and changing into m e s e n c h y m a l

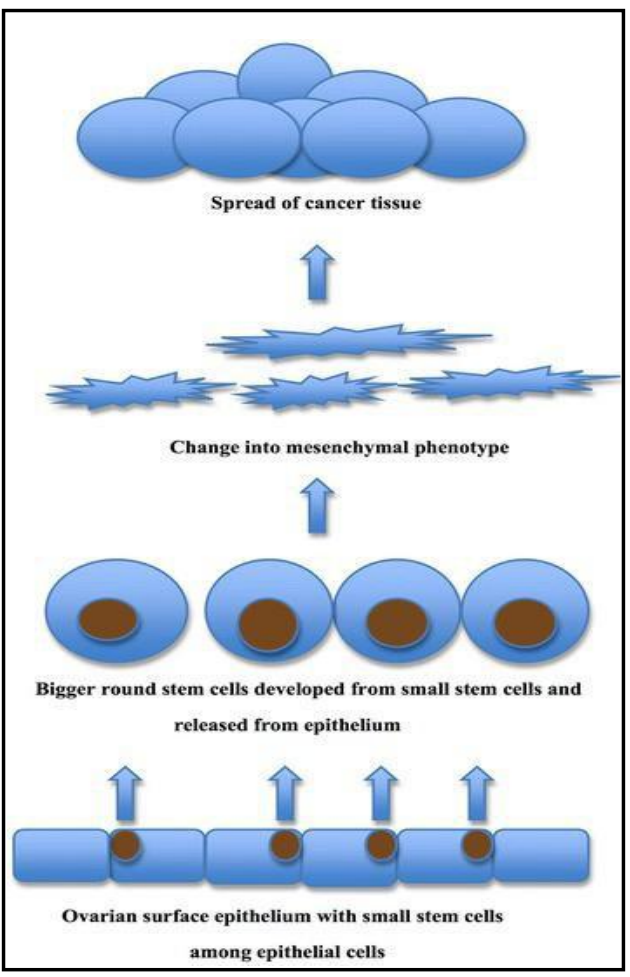
phenotype. The released small stem cells from OSE differentiate into bigger stem cells that further form oocytes or become CSCs. Mesenchymal cells arise by EMT of epithelial cells that will form granulosa cells (niche to growing oocyte) or niche to CSCs [32]. 


\section{Cellular Physiology Cell Physiol Biochem 2018;50:214-232

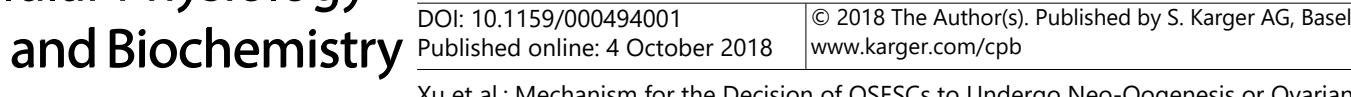 \\ Tumorigenesis}

This study experimentally supports the notion that susceptibility of transitional zones to malignant transformation may be explained by the presence of stem cell niches in those areas $[33,34]$. Identification of a stem cell niche for the OSE may have important implications for understanding epithelial ovarian cancer pathogenesis. High-grade serous adenocarcinomas occurring in transitional/junction regions between the OSE, mesothelium, and tubal epithelium may have more plastic and, presumably, less differentiated states, thereby being a possible place of origin for ovarian cancer. The stem cell niche for the stem cells lodged in ovarian surface epithelium (OSE), which is ruptured and regenerates during ovulation, has not yet been unequivocally defined. Flesken-Nikitin identified the hilum region of the mouse ovary, the transitional/junction area between OSE, mesothelium and tubal (oviductal) epithelium, as a previously unrecognized stem cell niche of the OSE [33].

\section{Ovarian surface epithelium stem cells and neo-oogenesis}

Stem cells are cells with self-renewal and differentiation potential in mammals that are found in almost all tissues and organs. They can renew themselves to maintain the numbers of stem cells in a stem cell pool, or they can renew loss of tissues or organs by differentiating. The presence of spermatogonial stem cells in testis was reported more than 40 years ago. Whether there are ovarian stem cells in female ovaries after birth to replenish the primordial follicle pool has been debated for nearly a century. Historically, it was believed that the majority of the primordial follicle pool remains in a dormant state and declines with age under physiological conditions [35]. At approximately age 50, female fertility begins to decline along with the continued depletion of the primordial follicle pool until the occurrence of menopause [36] . In 2004, Johnson et al. [37] were the first to discover that the ovaries of female mice from birth until adulthood can serve as a new supply of the oocyte follicle pool. Since then, studies on ovarian germline stem cells have been widespread among reproductive researchers around the world. There are now many different resources supporting this research, including from humans, other mammals, and even old ovarian surface epithelium ovarian germline stem cells isolated and successfully established as a stable subculture of germline stem cells [38-41]. Epithelial ovarian germline stem cells are an important source of egg production in adults. The OSE cell layer is considered to be "germinal epithelium" and has characteristics of embryonic stem cells. There are still scholars skeptical of the existence of ovarian germline stem cells in mammals [42], but Bukovsky [43] and Tilly [44] assert that this does not take into account samples of ovarian function and different experimental methods. More persuasive is a finding from Wu Ji with OGCs showing that they make infertile mice produce offspring. This study also successfully produced transgenic mice [45]. Furthermore, Reizel et al. demonstrate new egg formation in mice from birth to adulthood by lineage tracing in the body (in vivo lineage tracing), providing direct evidence for the existence of ovarian stem cells [46]. It is worth mentioning that we have also successfully isolated OGCs from mouse ovarian surface epithelial cells. These cells are elliptical, approximately 15-20 $\mu \mathrm{m}$, and few in number under the microscope. Their proliferation cycle is long, and they express MVH, OCT4, Nango, Fraglis, Stella, C-Kit and other germ cell- and stem cellspecific markers by PCR, providing further evidence for the existence of OGCs in mammalian ovaries after birth [47-51]. Recently, Wu et al. explored the process and mechanisms of OGC differentiation in vivo following transplantation. In this study, they isolated, purified, and cultured OGCs long term from a single EGFP-transgenic mouse and found that these OGCs possessed characteristics of germline stem cell with normal chromosomes, demonstrating that these cells were consistent with previously identified OGCs. More importantly, the OGCs from a single mouse restored ovarian function and generated offspring when transplanted into POF mouse ovaries. After tracing OGC migration and developmental patterns in vivo, they found that OGCs gradually differentiated into oocytes, but not somatic cells, suggesting unipotency. These findings provide the theoretical basis and lay a technology platform for specific or personalized medical treatment of ovarian failure or other ovarian diseases (Fig. 2).

\section{KARGER}




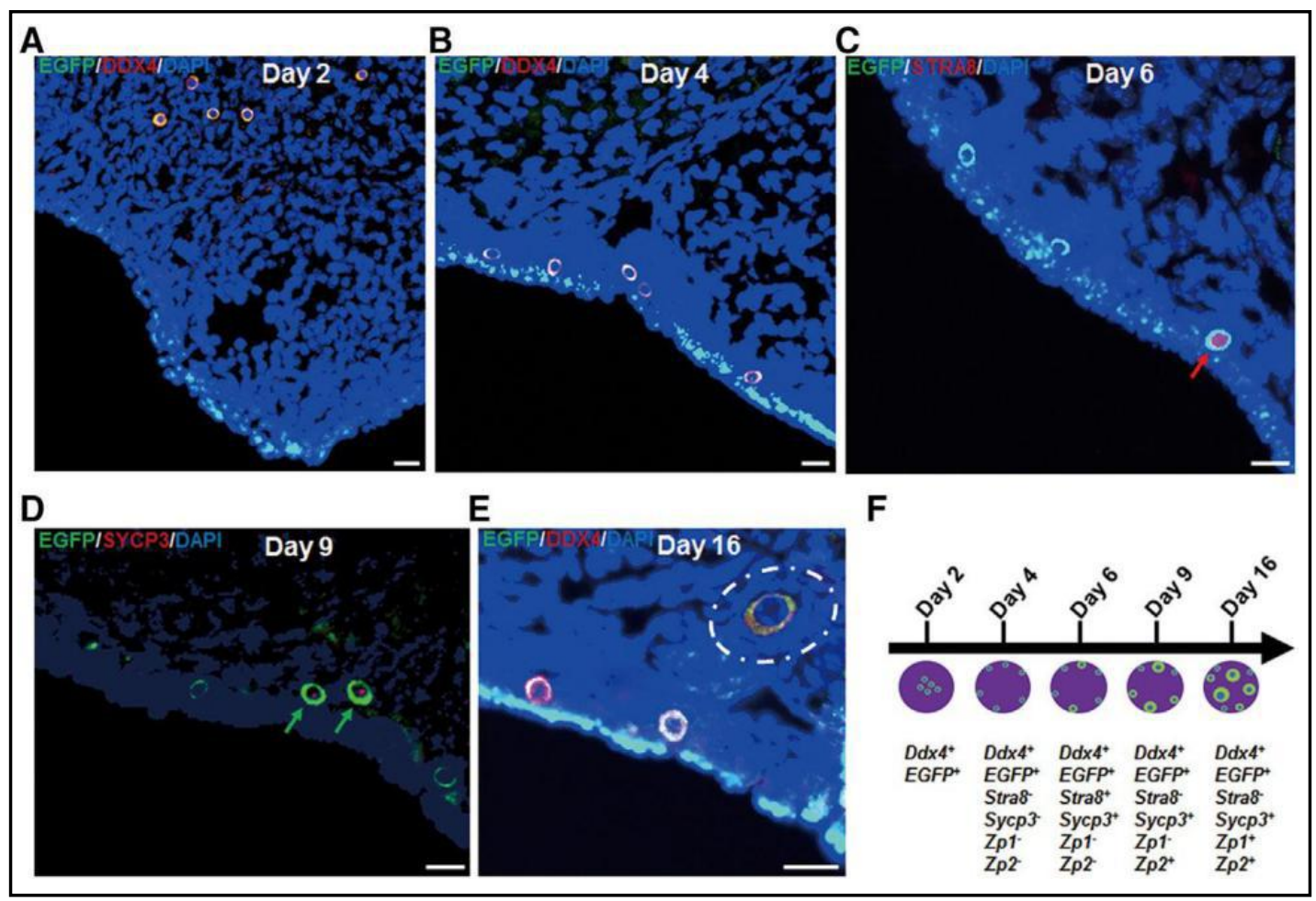

Fig. 2. Development of Transplanted OGSc In Vivo: (A and B) Immunofluorescence analysis of DDX4 and EGFP on days 2 (A) and 4 (B) after OGSc transplantation. Images show OGSc scattered in the ovary by day 2 , which migrated to the ovarian cortex surface by day 4 post-transplantation. Scale bars, $25 \mathrm{~mm}$. (C and D) Immunofluorescence analysis shows STRA8 expression (red arrow) in germ cells on day 6 (C) and SYCP3 expression (green 0 arrows) on day 9 (D) post-transplantation.Scale bars, $25 \mathrm{~mm}$. (E) A representative view of immunofluorescence analysis with DDX4 and EGFP on day 16 post-transplantation. White dashed oval indicates that the follicle contains an EGFP-labeled oocyte and somatic cells $(\mathrm{n}=5)$. Scale bar, $25 \mathrm{~mm}$. (F) Development model of transplanted OGSc in vivo. Arrow represents development process. Short line segments on arrow represent development time. Purple pans represent ovary.Blue and green represent the nucleus and cytoplasm of female germ cells (OGSc), respectively. Gene expression profiles of OGSc at different stages are listed below [52].

The existence of OGCs has a major impact for bioengineering, clinical treatment, and basic research because they can be used as a source of embryonic stem cells that are not questioned by religion, morality and ethics for therapeutic cloning and tissue therapy. These cells also provide a good basis for the study and treatment of fertility problems due to premature ovarian failure and aging and have great significance for the study of transgenic animals. There is a close relationship between epithelial stem cells and ovarian cancer; therefore, a model can be established to study the early events of ovarian carcinogenesis and to generate new findings for targeted therapy of ovarian cancer.

\section{Mechanism for the decision of ovarian surface epithelial stem cells to undergo neo-oogenesis or ovarian tumorigenesis}

\section{Intrinsic causes of ovarian surface epithelial stem cell conversion (transformation)}

It has been reported that ovarian carcinogenesis and progression of the disease is associated with epithelial-mesenchymal transition (EMT) [1, 52-54]. EMT is a physiological cell reprogramming event utilized in tissue remodeling during embryonic development and is activated in normal adult tissues during regeneration. EMT is defined as the loss

\section{KARGER}




\section{Cellular Physiology Cell Physiol Biochem 2018;50:214-232 \\ \begin{tabular}{ll|l} 
DOl: 10.1159/000494001 218 & $\begin{array}{l}\text { @ } 2018 \text { The Author(s). Published by S. Karger AG, Basel } \\
\text { www.karger.com/cpb }\end{array}$ \\
\cline { 2 - 3 } aublished online: 4 October 2018
\end{tabular} \\ Tumorigenesis}

of epithelial traits by the former epithelial cells with the acquisition of mesenchymal characteristics, such as invasive motility and the presence of vimentin and myosin [55]. During EMT, unique characteristics of certain mesenchymal cells are acquired, including epithelial cell polarity, intracellular adhesion and loss of specific cell surface markers. Due to cytoskeletal remodeling, these cells subsequently obtain a mesenchymal-like phenotype. The major molecular characteristics of EMT are downregulation of epithelial cell markers E-cadherin and $\beta$-catenin and upregulation mesenchymal markers vimentin, fibronectin and N-cadherin. During EMT, carcinoma cells lose their epithelial characteristics and acquire mesenchymal properties that promote extracellular matrix invasion and distant metastases [56]. OSE stem cells, through epithelial- mesenchymal transition (EMT), result in the development and progression of ovarian carcinoma mediated by multiple genes, including p53 mutations, KRAS, BRAF and PTEN, and PIK3CA mutations, and multiple signaling pathways, including the TGF- $\beta$ pathway, Wnt signaling pathway, Notch signal pathway, NF$\kappa \mathrm{B}$, the signal transducer and activator of transcription3 (STAT3) pathway and Hedgehog $(\mathrm{HH})$ pathway. These genes and pathways eventually lead to downregulation of epithelial cell markers E-cadherin and $\beta$-catenin and upregulation of mesenchymal phenotype markers vimentin, fibronectin, $\mathrm{N}$-cadherin, intracellular $\beta$-catenin nuclear translocation, and various transcription factors that regulate EMT, such as Twist, Snail, Slug, etc. [3, 57-59]. The genetic basis of epithelial ovarian carcinomas is too complex to be reviewed in detail here, but numerous excellent reviews exist on this subject [60-62]. Recently, lncRNAs, as well as epithelial ovarian cancer disease progression and the prognosis of patients, have attracted great interest. Since the expression of IncRNA is characterized by time-specificity, tissue-specificity and disease specificity, the functions of IncRNA in cancer development have drawn increasing attention, and as such, IncRNA is considered a potential tumor marker and therapeutic target. Non-protein-coding RNAs account for $70 \%$ of total RNAs in the body, and long non-coding RNAs (lncRNAs) consist of more than 200 nucleotides. IncRNAs have complicated functions in regulating gene expression [63-66]. In brief, compared with normal ovarian tissues and cell lines, the expression of a series of lncRNA caused expression changes in epithelial ovarian cancer tissues and cell lines. Qiu [67] found in epithelial ovarian cancer tissues and cell lines (SKOV3, H08910, and HEY-A8) that the IncRNA HOTAIR was increased in expression; Cheng [68] found that high expression of the lncRNA AB073614 in patients correlated with a decrease in 5-year survival rate. Sheng et al. [69] found that expression of MEG3 was absent or reduced in most epithelial ovarian cancer tissues and cell lines (OVCAR3). Current research shows that the development of epithelial ovarian carcinomarelated mechanisms for IncRNA includes controlling $\mathrm{X}$ chromosome inactivation, gene imprinting glucose regulation, promoting interaction between miRNAs, and development of drug resistance.

There are currently no reports on the mechanism of germ cell differentiation for OGSCs in the OSE. Our research found that Notch and Hippo signaling pathways may play key roles in OGSC differentiation. The Notch signaling pathway plays a crucial role in cell fate determination, cell proliferation and differentiation [70, 71]. Additionally, Notch is necessary for cell-cell communication and is involved in the proliferation and differentiation of various stem cells [72-74], especially the regulation of germline stem cells in invertebrates $[75,76]$. However, the role of the Notch pathway in germline stems cells of the mammalian ovary is still unknown. We used 3-d-, 2-m- and 20-m-old mouse ovaries to explore the correlation between germline stem cell activity and the Notch signaling pathway. Dual immunofluorescence staining showed that MVH is co-expressed with NOTCH1 in the OSE, and both of them are expressed at their highest level in 3-d-old mice, followed by 2-m-old mice, with very little expression observed in 20 -m-old mice. The same results were observed for MVH and HES1. In addition, for observing the proliferative activity of OGSCs in the OSE, we also detected co-expression between MVH and BrdU, with the strongest BrdU expression at 3-d, clearly decreased expression at 2-m and almost undetectable expression at 20-m. In summary, our results indicated that there is a correlation between germline stem cell activity and the Notch signaling pathway. To further confirm the link between germline stem 


\section{Cellular Physiology Cell Physiol Biochem 2018;50:214-232

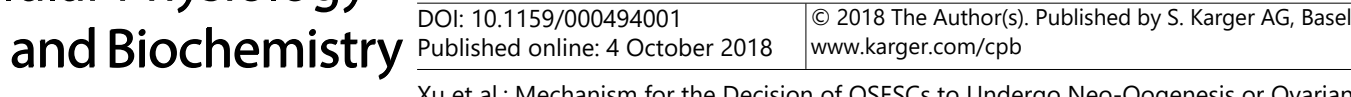 \\ Tumorigenesis}

cells and Notch in mouse ovarian tissues, 5- to 7-d-old mouse ovaries were isolated and treated with DAPT, an inhibitor of $\gamma$-secretase in the Notch signaling pathway. In our study, mouse ovaries were continuously exposed to DAPT for $48 \mathrm{~h}$. Compared to control, all DAPTtreated groups demonstrated reduced mRNA and protein expression of Mvh and Oct4. Dual immunofluorescence also revealed that DAPT-treated groups showed a slight attenuation of MVH and OCT4 expression in OSE compared to the control group. Therefore, our data suggest that the Notch signaling pathway may be a potential pathway involved in the regulation of germline stem cells [50]. The Hippo signaling pathway is a recently discovered novel signaling pathway [77] that, in mammals, comprises two upstream kinases (mammalian Sterile 20-like protein kinase I, MST1 and MST2, for short) and Salvador I (alsoknown as SAV1 or WW45), as well as large tumor suppressor homolog 1 and 2 (LATS1 and LATS2), and YAP1 (Yes-associated protein) [78, 79]. Hippo signaling has essential functions in the regulation of cancer stem cell proliferation, differentiation, migration and maturation, as well as the establishment of normal oocyte polarity and egg chamber structure [80-83]. YAP promotes ovarian CSC tumorigenesis and regulates CSC self-renewal and differentiation [84, 85]. The transcriptional co-activator with a PDZ-binding motif (TAZ) is a transcriptional effector of the Hippo signaling cascade that regulates cell proliferation and tumorigenesis $[80,86,87]$. Our results revealed that the Hippo signaling pathway and MVH/OCT4 genes are co-expressed in mouse ovarian cortex. The level and co-localization of LATS2, MST1, MVH, and OCT4 significantly decrease with increased age. Furthermore, YAP1, MVH, and OCT4 gradually decrease after TPT and CY/BUS treatment, and LATS2 mRNA and protein upregulation persist in TPT- and CY/BUS-treated mice. However, the expression of MST1 was lower in the TPT and CY/BUS groups compared with the control group. In addition, pYAP1 protein showed the highest expression in the ovarian cortex of 7D mice compared with 20M mice, and the value of pYAP1/YAP1 decreased from 7D to 20M. Moreover, pYAP1 decreased in the TPT-and CY/BUS-treated groups, but the value of pYAP1/YAP1 increased in these groups. Our results show that the Hippo signaling pathway is associated with the changes that occur in OGSCs during physiological and pathological ovarian aging in mice. Thus, the Hippo signaling pathway may be involved in the developmental schedule of OGSCs [47]. Further results indicate that isolated OGSCs can specifically recognize Hippo signaling molecules and that manipulation of YAP1 expression can be used to regulate proliferation and differentiation of OGSCs, as well as ovarian function in mice. This study suggests that the Hippo signaling pathway may represent a new molecular target for regulation of mouse ovarian functional remodeling [51].

\section{Extrinsic causes of ovarian surface epithelial stem cell conversion (transformation)}

The hypothesis of incessant ovulation. Cancer is now generally believed to be a preventable disease. Only $5-10 \%$ of all cancers are caused by the inheritance of mutated genes and somatic mutations, whereas the remaining $90-95 \%$ has been linked to lifestyle factors and environment [86]. The sequence of events leading to ovarian cancer is multifactorial and not adequately understood. Except those with a family history of ovarian cancer, accounting for $5-10 \%$ of cases, the major known environmental risk factors that have been implicated in playing a role include diet, talc, industrial pollutants, smoking, asbestos, and infectious agents [87-89]. Epidemiological studies point to possible racial and geographic, social, and hormonal causative factors [90-93]. There are two theories to explain the pathogenesis of ovarian cancer. One is the 'incessant ovulation hypothesis'. It appears that the first step in tumorigenesis involves genomic disturbances to the ovarian surface epithelium that arise during ovulation (Fig. 3). After ovulation, the damaged ovarian epithelium transforms into mesenchymal cells, proliferates, and migrates, thus speeding up tissue repair. If the process appears abnormal, it will continue to promote the occurrence and development of EMT, leading to neoplastic transformation of OSE cells, ultimately resulting in ovarian cancer (Fig. 3 ). The 'incessant ovulation hypothesis' of ovarian cancer was first proposed by Fathalla in 1971 [94], and the following facts support to this hypothesis [95, 96]: 1) there is convincing evidence that nulliparity and probably hyper-ovulation treatment for infertility increases 


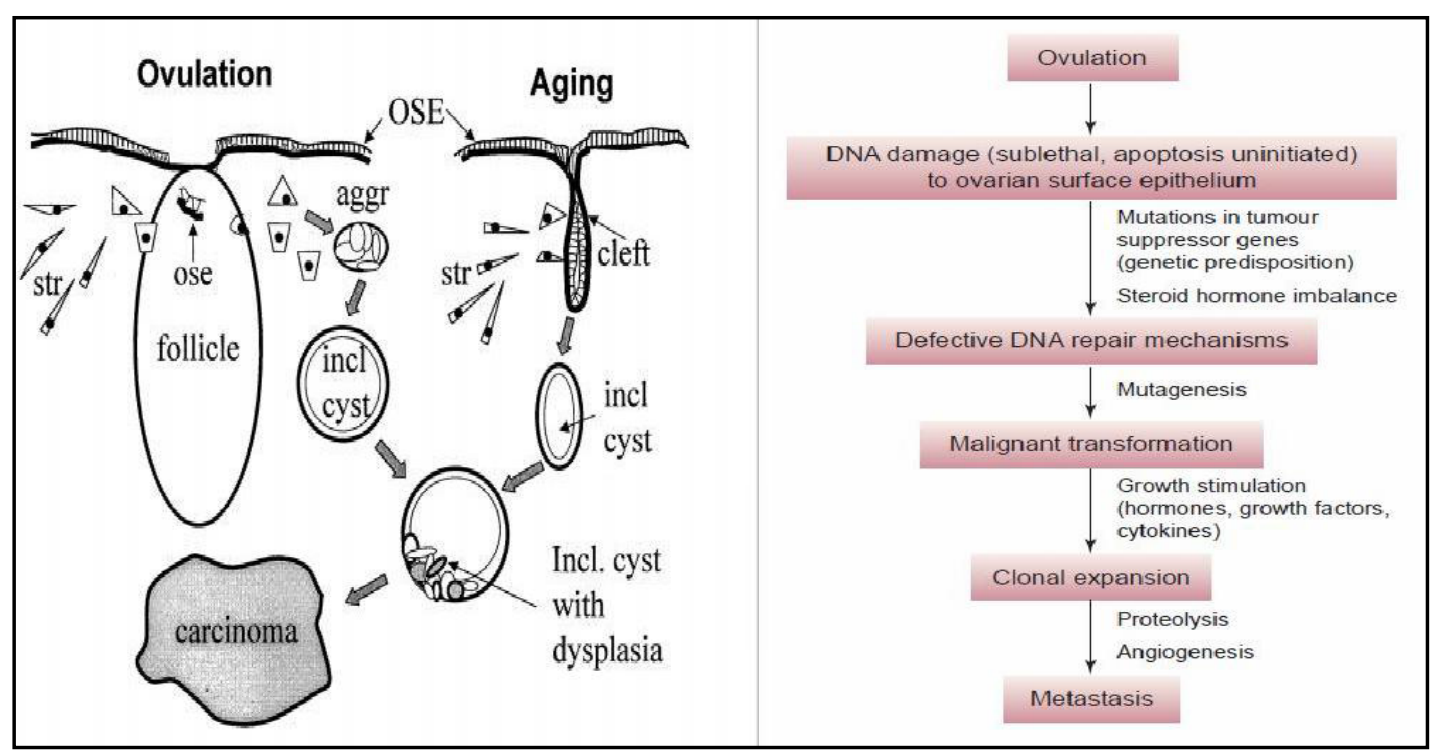

Fig. 3. Prospective role of ovulation in the chronology of ovarian carcinogenesis. Hypothesis: Epitheliomesenchymal conversion of OSE cells may represent a homeostatic mechanism to incorporate cells that have been displaced from the ovarian surface into the stroma. If such conversion does not take place, the cells are more likely to form epithelial inclusion cysts, which are preferred sites of neoplastic progression. A, diagram outlining two paths by which OSE is displaced into the ovarian cortex. OSE fragments are displaced into or near the ruptured follicle at ovulation. OSE also lines surface invaginations, or clefts, which form as the ovary ages. If OSE cells undergo epithelio-mesenchymal conversion, they may migrate into, and become part of, the stroma (str). Alternatively,the cells remain epithelial, aggregate (aggr), and form inclusion cysts (incl cyst). Cysts may also form through the pinching off of surface clefts.Inclusion cysts are preferred sites of metaplastic and dysplastic changes that may lead to tumorigenesis. Importantly, the capacity of OSE to undergo epithelio-mesenchymal conversion is greatly reduced with malignant progression and, to a lesser degree, in women with a genetic predisposition to develop ovarian cancer [94, 97].

the risk of ovarian cancer, while oral contraceptives, pregnancies and lactation are protective (by approximately 40\%); 2) frequent ovulation, without long dormant periods, contributes to increased risk because the repeated rupture and repair of the OSE at the sites of ovulation provide an opportunity for genetic aberrations to accumulate; 3) ovulation, and therefore ovarian cancer, is more common in human women than it is in most other species because females of other species are either pregnant or lactating for most of their reproductive lives;4) it appears that the first step in tumorigenesis involves genomic disturbances to the ovarian surface epithelium that arise from ovulation. Inflammatory mediators and reactive oxidants are generated during the ovulatory process that causes wounding of ovarian surface epithelial cells with DNA strand breaks, and oxidative base (8-oxoguanine) damage could be a determinant of carcinogenic onset. Studies carried out on genetically modified mice do not support the 'incessant ovulation hypothesis', but support the gonadotropin hypothesis. Sterile, germ cell-deficient homozygous $\mathrm{Wv}$ mice having $<1 \%$ of the normal number of oocytes at birth develop epithelial morphological changes including surface invaginations, inclusion cysts, and tumors associated with elevated gonadotropin levels similar to aged women [97]. Furthermore, these mice, being sterile, never ovulate, and thus, the concept of incessant ovulation does not explain the origin of ovarian cancer in these mice. Similarly, more than $90 \%$ of FORKO mice develop ovarian epithelial tumors by 12 months of age, which are otherwise sterile and never ovulate [98]. Smith \& Xu [99] have postulated that depletion of follicles and germ cells might underlie the etiology of ovarian cancers.

The gonadotropin theory. The 'gonadotropin theory' of cancer was first proposed by Stadel in 1975 [100]. This hypothesis is supported by several pieces of circumstantial

\section{KARGER}




\section{Cellular Physiology Cell Physiol Biochem 2018;50:214-232

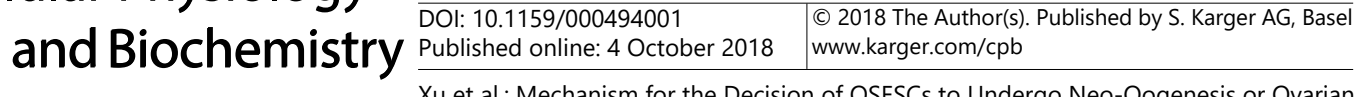 \\ Tumorigenesis}

evidence, including 1) increased incidence of ovarian cancers with advanced age when gonadotropin levels are elevated; 2) high FSH levels in ovarian cysts and peritoneal fluid; 3 ) protective effect of breastfeeding and multi-parity that help suppress gonadotropin levels; and 4) increased risk of developing ovarian cancer in women with polycystic ovarian syndrome (PCOS) and those undergoing hyper-stimulation of ovaries with FSH. Several recent reviews have elegantly discussed the available literature suggesting that FSH, in particular, may be the main hormone responsible for ovarian cancers [101-107]. High levels of FSH and FSH receptor (FSHR) expression in epithelial ovarian cancers (EOCs) are associated with a poor prognosis. FSH affects various aspects of ovarian cancer metastasis, such as suppressing apoptosis, supporting tumor growth by inducing increased expression of VEGFA (VEGF), facilitating blood vessel growth, and potentially altering certain oncogenic pathways that facilitate proliferative and invasive phenotypes. Bhartiya asserts that ovarian stem cells (OSCs) existing in the OSE are responsible for neo-oogenesis and primordial follicle assembly in adult life and are modulated by FSH via its alternatively spliced receptor variant FSHR3 (growth factor type 1 receptor acting via calcium signaling and the ERK/ MAPK pathway) [107]. Any defect in FSH - FSHR3 - stem cell interaction in the OSE may affect folliculogenesis and thus result in POF. Ovarian aging is associated with a compromised microenvironment that does not support stem cell differentiation into oocytes or further folliculogenesis. FSH exerts a mitogenic effect on the OSE, and elevated FSH levels associated with advanced age may provide a continuous trigger for stem cells to proliferate, resulting in cancer and supporting the gonadotropin theory for ovarian cancer [108]. However, the gonadotropin hypothesis for the development of ovarian cancers is still not well accepted because one needs to remember that increased FSH is present in all aged, including menopausal women but only few suffer from ovarian cancer. Thus, in the last decade, there has been a broad range of research focused on the role of immunological mechanisms and chronic inflammation affecting OGSC differentiation to ovarian cancer cells [109].

\section{Immunosuppressive mechanisms and chronic inflammation}

It is well known that as age increases, the immune system declines in function, which is called immune aging. Middle-aged and elderly women who are experiencing immune aging are the group most at risk to develop ovarian cancer. Both epidemiological and clinical evidence has indicated a strong association between immunosuppressive mechanisms and inflammatory state in the tumor microenvironment. Accumulating data have established the notion that the tumor microenvironment is largely orchestrated by infiltrating immune cells, including $\mathrm{T}$ lymphocytes, macrophages, dendritic cells, and mast cells. These cells are recruited to the tumor stroma and cooperate with each other, either to facilitate initiation, invasion, migration and metastasis of the tumor or to elicit anti-tumor immunity [110]. Recent studies are focusing on the role of the immune system in ovarian cancer pathogenesis. It has been reported that an immune response against ovarian cancer cells may be inhibited by a number of immunosuppressive mechanisms active in the cancer microenvironment, suggesting ovarian cancer creates a suppressive microenvironment to escape immune elimination. It causes difficulties in immune recognition and the destruction of cancer cells, leading to the development of immune tolerance and is associated with a low efficacy of standard therapeutic strategies [111]. Inflammation is the body's response to infection and is a strong, quick stress response.

Typically, this reaction will promptly terminate after the infection has been effectively controlled. Therefore, in most cases, inflammation does not induce a tumor. If inflammation persists, causing excessive stress and tissue damage, it will likely lead to cancer. Over the last decade, a large amount of evidence indicates that inflammation contributes to tumorigenesis. For example, transcription factors nuclear factor- $\kappa$ B (NF- $\kappa B$ ) and signal transducers and activators of transcription 3 (STAT3), two major pathways for inflammation, are activated by most cancer risk factors; an inflammatory condition precedes most cancers; NF- $\kappa$ B and STAT3 are constitutively active in most cancers; hypoxia and acidic conditions found in solid tumors activate NF- $\kappa$ B; chemotherapeutic agents and $\gamma$-irradiation activate NF- $\kappa$ B and 


\section{Cellular Physiology Cell Physiol Biochem 2018;50:214-232

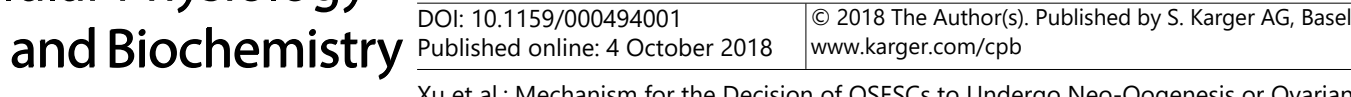 \\ Tumorigenesis}

lead to chemoresistance and radioresistance; most gene products linked to inflammation, survival, proliferation, invasion, angiogenesis, and metastasis are regulated by NF- $\kappa \mathrm{B}$ and STAT3; suppression of NF- $\kappa B$ and STAT3 inhibits proliferation and invasion of tumors; and most chemopreventive agents mediate their effects through inhibition of NF- $\mathrm{BB}$ and STAT3 activation pathways $[112,113]$. Many cancers result from chronic inflammation triggered by either extrinsic factors, [114] such as infection, autoimmunity, and tobacco smoke, or intrinsic factors, such as oncogene activatio [115]. Chronic inflammatory responses produce cytokines and growth factors that may promote cell proliferation and suppress apoptosis, and both of these outcomes result in an increased risk of cancer. The causal link between inflammation and tumor initiation is well established [116]. When subject to persistent microbial infection or chronic stimulation, macrophages recognize the foreign materials and activate transcriptional mechanisms that lead to secretion of pro-inflammatory cytokines and chemokines $[117,118]$. However, excessively produced cytokines can also sustain a state of chronic inflammation and promote tumor initiation. In established tumors, tumorassociated macrophages (TAMs) facilitate tumor cell migration, invasion, matrix remodeling and angiogenesis, which are required for tumor cells to escape from primary sites into the circulatory system and form metastases. In tumor microenvironments, anti-inflammatory cytokines, such as IL-4, IL-13, IL-10 and M-CSF, induce the transition of TAMs from a proinflammatory state to a tumor-promoting one [119].

One promising strategy to meet the challenge of improving ovarian cancer survival rates is to exploit the immune system and re-educate it to enhance tumor cell destruction [120]. Indeed, it has been widely reported that a higher density of TILs, such as T and B lymphocytes, is associated with increased overall survival and chemo-radiosensitivity in OC [121-124]. Previous reports have confirmed that higher levels of the cytokines IL-6 and VEGF are associated with chemoresistance, are both markers for poor prognosis in OC and exhibit pro-tumorigenic effects, such as promoting angiogenesis $[125,126]$. These studies highlight key insights that are applicable to both basic OC research and to the prevention and treatment of OC.

In addition to its role in maintaining organism homeostasis, the immune system also plays a crucial role in the modulation of ovarian function, as it regulates ovarian development, follicular maturation, ovulation and the formation of the corpus luteum [127131]. In recent years, studies have also shown that immunosuppressive mechanisms and chronic inflammation play an important role in the pathogenesis of ovarian premature aging. A large amount of research has confirmed that levels of TNF- $\alpha$ and IL-2 in the serum of patients with premature ovarian failure were significantly lower than those in unaffected group. Furthermore, the level of inflammatory factors decreased when the damaged ovarian function was repaired, indicating that inflammatory factors may be an important cause of premature ovarian failure [132-135]. Levels of inflammatory factors such as TNF- $\alpha$, IL-1 $\beta$, IL-2, IL-6, colony stimulating factor, zinc finger protein A20, heme oxygenase (HO-1) and many others are regulated by NF- $\kappa \mathrm{B}$. NF- $\kappa \mathrm{B}$ is a transcription factor that can turn on genes related to inflammation and immune response. These results suggest that we can prevent ovarian failure through anti-inflammatory factors that regulate NF- $\kappa B$ signaling pathway. For example, resveratrol restores ovarian function through inhibiting NF- $\kappa \mathrm{B}$ and reducing ovarian inflammation through IL-6 and IL-8 expression [136, 137]. Interestingly, recent work has postulated that immune cells and their secreted inflammatory factors follow mechanics to regulate the proliferation and differentiation of ovarian germline stem cells $[48,138]$. First, immunity may be a part of the OSC niche. Bukovsky [138] postulates that the OSC niche contains immune cells and their secreted factors. The OSC niche is established during early stages of fetal development and consists of committed ovarian monocyte-derived cells (MDCs), T cells and vascular endothelial cells. In contrast, the adult OSC niche contains primary MDCs (CD14+ MDC), activated MDCs ([HLA-DR] + MDC) and T cells. Second, factors within the OSC niche control OSC differentiate into oocytes and granulosa cells. When OSCs differentiate into reproductive cells, they must then accept ovary-committed bone marrow cells (OCMT), which in turn stimulate MDCs and T cells $[139,140]$. OSCs can produce one 


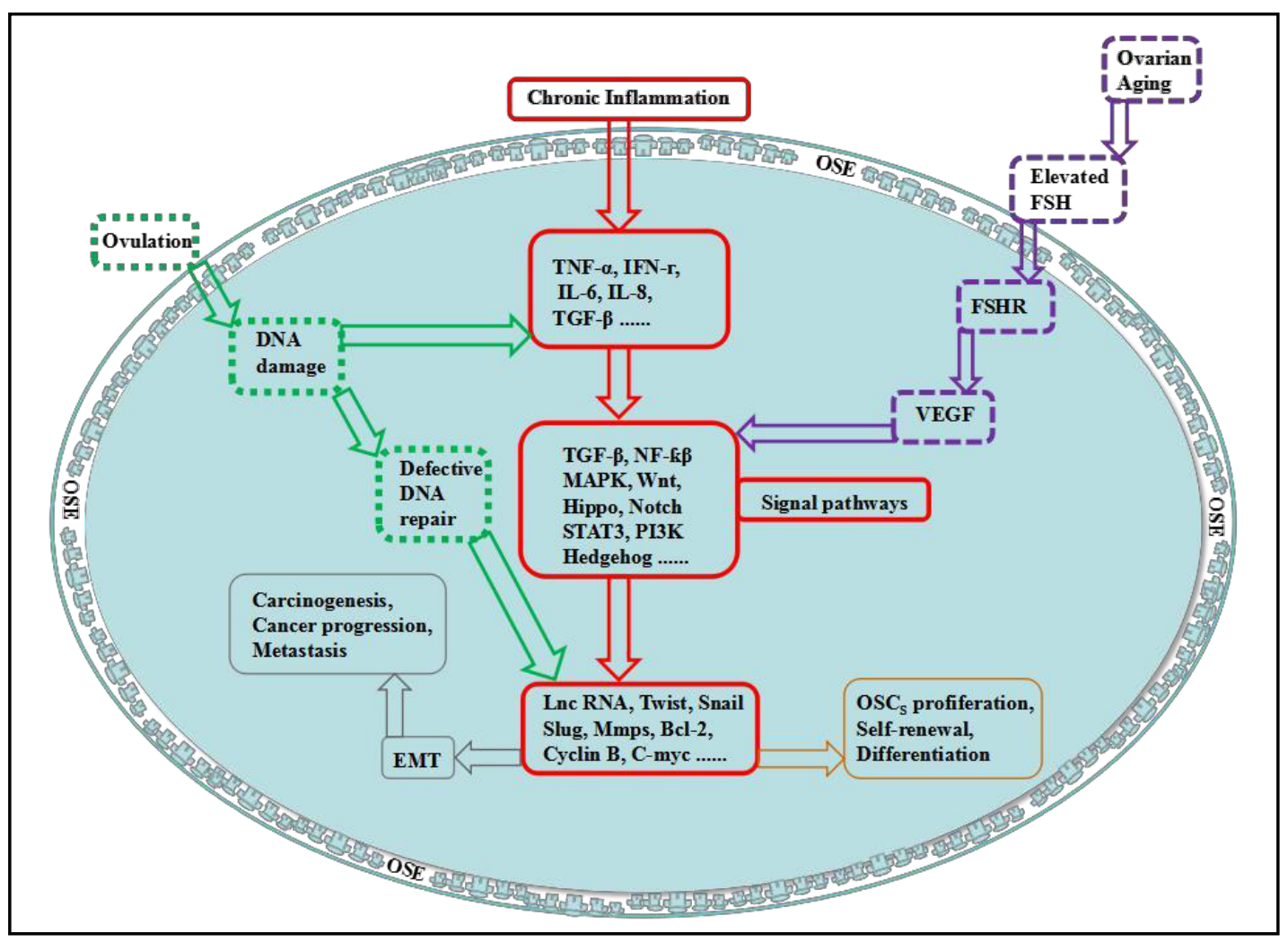

Fig. 4. Signaling pathways and genes of ovarian surface epithelial stem cells to undergo neo-oogenesis or ovarian tumorigenesis induced by ovulation, chronic inflammatory and elevated FSH. TNF- $\alpha$, tumor necrosis factor $\alpha$; IFN-г, interferon- $\gamma$; IL-6, interleukin 6; IL-8, interleukin 8; TGF- $\beta$, transforming growth factor- $\beta$; FSHR, follicle stimulating hormone receptor; VEGF, vascular endothelial growth factor; TGF- $\beta$, transforming growth factor- $\beta$; NF- $\mathrm{k} \beta$, nuclear factor- $\mathrm{kB}$; MAPK, mitogen-activated protein kinase; Wnt, Wingless Int1; Hippo, Hippo signaling pathway; Notch, notches; STAT3, Signal transducers and activators of transcription 3; PI3K, Phosphoinositide 3-kinase; Hedgehog,Lnc RNA, Long non-coding RNA;Twist, Twist-related protein 1; Snail, Snail signaling pathway; Slug, Slug signaling pathway; Mmps, Mmps signaling pathway; Matrix metalloproteinases; Bcl-2, B-cell lymphoma-2; Cyclin B, Cyclin B signaling pathway; C-myc, C-myc signaling pathway; OSCS, ovarian stem cells.

differentiated germ cell and one progeny OSC. The germ cell can then differentiate into an oocyte and migrate to the epithelial layer adjacent to blood vessels in the ovarian cortex. As a consequence of normal circulatory function, germ cells will develop and interact with granulosa cells to form primitive follicles [141]. The development and migration of germ cells occur in the context of immune cells such as CD14+ MDCs and requires asymmetric OSC division. Moreover, symmetric germ cell division is accompanied by CD8+ T cells and is assisted by primary MDCs. Ultimately, primary MDCs facilitate differentiation of germ cells to epithelial cells, while activated MDCs (DR+ MDC) are involved in germ cell migration. When OSCs are cultured together with macrophages and IL-I $\beta$ and IL-18, there is an obvious effect on OSC proliferation and differentiation of anti-aging cells (unpublished data), further suggesting that immunity and inflammatory factors play an important role in proliferation and differentiation of germline stem cells.

\section{Conclusion}

Ovarian stem cells existing in the epithelium of the ovary are closely related to both follicular renewal and development of ovarian cancer. Ovarian stem cells may either become 


\section{Cellular Physiology Cell Physiol Biochem 2018;50:214-232

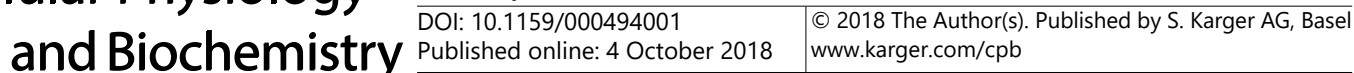 \\ Xu et al.: Mechanism for the Decision of OSESCs to Undergo Neo-Oogenesis or Ovarian \\ Tumorigenesis}

ovarian carcinomas or participate in follicular renewal, depending on intracellular signaling pathways, LncRNA genes, and extracellular factors, such as FSH, follicular rupture, and immune microinflammation (Fig. 4). However, further study is needed to determine how many common mechanisms regulate the development of ovarian stem cells to follicular renewal or ovarian cancer? How do these common mechanisms work together in time and space to precisely regulate the differentiation of ovarian stem cells in opposing directions?

How do these factors interact? Ovarian epithelial stem cells exist in one or both circumstances, so what is the difference and what is the connection? The resolution of these problems will undoubtedly result in major breakthroughs in the prevention and treatment of infertility, ovarian aging and ovarian cancer.

\section{Acknowledgements}

The authors would like to thank Dr. Yuehui Zheng for article mentoring, We also thank the members in our lab who participated in this article. This work was supported by the National Nature Science Foundation of China (No. 81671455, 81360100), the Natural Science Foundation of Jiangxi province (No. 20152ACB20023, 20161BAB205207, 20161BAB205213).

\section{Disclosure Statement}

The authors declare no conflicts of interest.

\section{References}

1 Ahmed N, Thompson EW, Quinn MA: Epithelial-mesenchymal interconversions in normal ovarian surface epithelium and ovarian carcinomas: an exception to the norm. J Cell Physiol 2007;213:581-588.

2 Okamoto S, Okamoto A, T, Saito M, Takao M, Yanaihara N, Takakura S, Ochiai K, Tanaka T: Mesenchymal to epithelial transition in the human ovarian surface epithelium focusing on inclusion cysts. Oncol Rep 2009;21:1209-1214.

-3 Zhu Y, Nilsson M, Sundfeldt K: Phenotypic plasticity of the ovarian surface epithelium: TGF-beta 1 induction of epithelial to mesenchymal transition (EMT) in vitro. Endocrinology 2010;151:5497-5505.

- 4 Zou K, Yuan Z, Z, Luo H, Sun K, Zhou L, Xiang J, Shi L, Yu Q, Zhang Y, Hou R: Production of offspring from a germline stem cell line derived from neonatal ovaries. Nat Cell Biol 2009;11:631.

-5 Zhang Y, Yang Z, Yang Y, Wang S, Shi L, Xie W, Sun K, Zou K, Wang L, Xiong J: Production of transgenic mice by random recombination of targeted genes in female germline stem cells. J Mol Cell Biol 2011;3:132-141.

-6 White YAR, Woods DC, Takai Y, Ishihara O, Seki H, Tilly JL: Oocyte formation by mitotically active germ cells purified from ovaries of reproductive-age women. Nat Med 2012;18:413-421.

7 Zhou L, Wang L, Kang JX, Xie W, Li X, Wu C, Xu B, Wu J: Production of fat-1 transgenic rats using a post-natal female germline stem cell line. Mol Hum Reprod 2014;20:271-281.

-8 Ding X, Liu G, Xu B, Wu C, Hui N, Ni X, Wang J, Du M, Teng X, Wu J: Human GV oocytes generated by mitotically active germ cells obtained from follicular aspirates. Sci Rep 2016;6:28218.

-9 Hummitzsch K, Anderson RA, Wilhelm D, Wu J, Telfer EE, Russell DL, Robertson SA, Rodgers RJ: Stem cells, progenitor cells, and lineage decisions in the ovary. Endocr Rev 2015;36:65-91.

10 Nicosia SV, Saunders BO, Acevedo-Duncan ME, Setrakian S, Degregorio R: Biopathology of Ovarian Mesothelium, Springer US1991.

11 Auersperg N, Wong A, Choi K, Kang S, Leung P: Ovarian surface epithelium: biology, endocrinology, and pathology. Endocr Rev 2001;22:255-288.

12 Jacobs I, Jr BR: The CA 125 tumour-associated antigen: a review of the literature. Hum Reprod 1989;4:1-12. 


\section{Cellular Physiology Cell Physiol Biochem 2018;50:214-232 and Biochemistry Published on \begin{tabular}{l|l} 
DOI: 10.1159/000494001 & $\begin{array}{l}\text { C } 2018 \text { The Author(s). Published by S. Karger AG, Basel } \\
\text { www.karger.com/cpb }\end{array}$
\end{tabular}

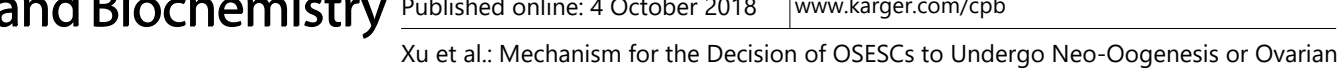 \\ Tumorigenesis}

13 Byskov AG, Skakkebaek NE, Stafanger G, Peters H: Influence of ovarian surface epithelium and rete ovarii on follicle formation. J Anat 1977;123:77-86.

$\checkmark 14$ Stein LE, Anderson CH: A qualitative and quantitative study of rete ovarii development in the fetal rat: correlation with the onset of meiosis and follicle cell appearance. Anat Rec 1979;193:197-211.

15 Yoshinaga K, Hess DL, Hendrickx AG, Luciano ZMD: The development of the sexually indifferent gonad in the prosimian, Galago crassicaudatus crassicaudatus. Dev Dynam 1988;181:89-105.

-16 Hirshfield AN: Development of follicles in the mammalian ovary. Int Rev Cytol 1991;124:43-101.

17 Pan J, Auersperg N: Spatiotemporal changes in cytokeratin expression in the neonatal rat ovary. Biochem cell biol 1998;76:27-35.

18 Blaustein A, Lee H: Surface cells of the ovary and pelvic peritoneum: a histochemical and ultrastructure comparison. Gynecol Oncol 1979;8:34-43.

19 Auersperg N, Maines-Bandiera SL, Dyck HG, Kruk PA: Characterization of cultured human ovarian surface epithelial cells: phenotypic plasticity and premalignant changes. 1994;71:510-518.

20 Zhang S, Zhang HS, Cordoncardo C, Reuter VE, Singhal AK, Lloyd KO, Livingston PO: Selection of tumor antigens as targets for immune attack using immunohistochemistry: II. Blood group-related antigens. Int J Cancer 1997;73:50.

-21 Kruk PA, Uitto VJ, Firth JD, Dedhar S, Auersperg N: Reciprocal interactions between human ovarian surface epithelial cells and adjacent extracellular matrix. Exp Cell Res 1994;215:97-108.

-22 Séverine Cruet MS, Clara Salamanca BS, G.W.Erle Mitchell MB, Ch.B, Nelly Auersperg, Ph. D: $\alpha v \beta 3$ and Vitronectin Expression by Normal Ovarian Surface Epithelial Cells: Role in Cell Adhesion and Cell Proliferation. Gynecol Oncol 1999;75:254-260.

-23 Sundfeldt K, Piontkewitz Y, Ivarsson K, Nilsson O, Hellberg P, Brännstr, Ouml:M M, Janson PO, Enerbäck $\mathrm{S}$, Hedin L: E-cadherin expression in human epithelial ovarian cancer and normal ovary. Int J Cancer 1997;74:275.

24 Blaustein A, Kaganowicz A, Wells J: Tumor markers in inclusion cysts of the ovary. Cancer 1982;49:722.

-25 Mittal KR, Goswami S, Demopoulos RI: Immunohistochemical profile of ovarian inclusion cysts in patients with and without ovarian carcinoma. Histochem J 1995;27:119-122.

26 van Niekerk CC, Boerman OC, Ramaekers FC, Poels LG: Marker profile of different phases in the transition of normal human ovarian epithelium to ovarian carcinomas. Am J Pathol 1991;138:455-463.

-27 Radisavljevic SV: The pathogenesis of ovarian inclusion cysts and cystomas. Ob Gyn. 1977;49:424-429.

28 Murdoch WJ: Ovarian surface epithelium during ovulatory and anovulatory ovine estrous cycles. Anat Rec 1994;240:322-326.

29 Kurman RJ, Iem S: The origin and pathogenesis of epithelial ovarian cancer: a proposed unifying theory. Am J Surg Pathol 2010;34:433-443.

30 Wright JW, Pejovic T, Lawson M, Jurevic L, Hobbs T, Stouffer RL: Ovulation in the Absence of the Ovarian Surface Epithelium in the Primate. Biol Reprod 2010;82:599-605.

-31 Wright JW, Pejovic T, Jurevic L, Bishop CV, Hobbs T, Stouffer RL: Ovarian surface epitheliectomy in the non-human primate: continued cyclic ovarian function and limited epithelial replacement. Hum Reprod 2011;26:1422-1430.

-32 Suster NK, Smrkolj S, Virant-Klun I: Putative stem cells and epithelial-mesenchymal transition revealed in sections of ovarian tumor in patients with serous ovarian carcinoma using immunohistochemistry for vimentin and pluripotency-related markers. J Ovarian Res 2017;10:11.

33 Fleskennikitin A, Hwang CI, Cheng CY, Michurina TV, Enikolopov G, Nikitin AY: Ovarian surface epithelium at the junction area contains cancer-prone stem cell niche. Nature 2013;495:241-245.

-34 Lengyel E: Ovarian Cancer Development and Metastasis. Am J Pathol 2010;177:1053-1064.

-35 Mcgee EA, Hsueh AJ: Initial and cyclic recruitment of ovarian follicles. Endocr Rev 2000;21:200-214.

-36 Adhikari D, Liu K: Molecular mechanisms underlying the activation of mammalian primordial follicles. Endocr Rev 2009;30:438-464.

37 Johnson J, Canning J, Kaneko T, Pru JK, Tilly JL: Germline stem cells and follicular renewal in the postnatal mammalian ovary. Nature 2004;428:145-150.

38 Liu J, Shang D, Xiao Y, Zhong P, Cheng H, Zhou R: Isolation and characterization of string-forming female germline stem cells from ovaries of neonatal mice. J Biol Chem 2017;292:16003.

-39 TGF- $\beta$ Family Signaling in Embryonic and Somatic Stem Cell Renewal and Differentiation. Cold Spring Harp Perspect Biol 2017;9:a022186. 


\section{Cellular Physiology Cell Physiol Biochem 2018;50:214-232 \begin{tabular}{l|l|l} 
and Biochemistry Published online: 4 October 2018 & $\begin{array}{l}\text { ○ 2018 The Author(s). Published by S. Karger AG, Basel } \\
\text { www.karger.com/cpb }\end{array}$ \\
\hline
\end{tabular}}

Xu et al.: Mechanism for the Decision of OSESCs to Undergo Neo-Oogenesis or Ovarian

Tumorigenesis

40 Hu Y, Bai Y, Chu Z, Wang J, Wang L, Yu M, Lian Z, Hua J: GSK3 inhibitor-BIO regulates proliferation of female germline stem cells from the postnatal mouse ovary. Cell Proliferat 2012;45:287-298.

41 Woods DC, Tilly JL: The next (re)generation of ovarian biology and fertility in women: is current science tomorrow's practice? Fertil Steril 2012;98:3-10.

-42 Zhang H, Zheng W, Shen Y, Adhikari D, Ueno H, Liu K: Experimental evidence showing that no mitotically active female germline progenitors exist in postnatal mouse ovaries. P Natl Acad Sci USA 2012;109: 1258012585.

43 Bukovsky A: Ovarian stem cell niche and follicular renewal in mammals. Anat Rec 2011;294:1284-1306.

-44 Woods DC, White YAR, Tilly JL: Purification of Oogonial Stem Cells From Adult Mouse and Human Ovaries: An Assessment of the Literature and a View Toward the Future. Reprod Sci 2013;20:7.

$45<$ Upregulation of Integrin- $\alpha 6$ and Integrin- $\beta 1$ Gene Expressions in Mouse Spermatogonial Stem Cells after Continues and Pulsed Low Intensity Ultrasound Stimulation.pdf>. 10.22074/cellj.2018.4286.

-46 Reizel Y, Itzkovitz S, Adar R, Elbaz J, Jinich A, Chapalilani N, Maruvka YE, Nevo N, Marx Z, Horovitz I: Cell Lineage Analysis of the Mammalian Female Germline. Plos Genet 2012;8:e1002477.

47 Li J, Zhou F, Zheng T, Pan Z, Liang X, Huang J, Zheng L, Zheng Y: Ovarian Germline Stem Cells (OGSCs) and the Hippo Signaling Pathway Association with Physiological and Pathological Ovarian Aging in Mice. Cell Physiol Bioche 2015;36:1712-1724.

48 Ye H, Li X, Zheng T, Liang X, Li J, Huang J, Pan Z, Zheng Y: The effect of the immune system on ovarian function and features of ovarian germline stem cells. Springerplus 2016;5:990.

49 Pan Z, Sun M, Liang X, Li J, Zhou F, Zhong Z, Zheng Y: The Controversy, Challenges, and Potential Benefits of Putative Female Germline Stem Cells Research in Mammals. Stem Cells Int 2016,(2015-12-15) 2015;2016:1-9.

-50 Pan Z, Sun M, Li J, Zhou F, Liang X, Huang J, Zheng T, Zheng L, Zheng Y: The Expression of Markers Related to Ovarian Germline Stem Cells in the Mouse Ovarian Surface Epithelium and the Correlation with Notch Signaling Pathway. Cell Physiol Bioche 2015;37:2311-2322.

-51 Ye H, Li X, Zheng T, Hu C, Pan Z, Jian H, Wei L, Jia L, Zheng Y: The Hippo Signaling Pathway Regulates Ovarian Function via the Proliferation of Ovarian Germline Stem Cells. Cell Physiol Bioche 2017; 41:10511062.

52 Wu C, Xu B, Li X, Ma W, Zhang P, Chen X, Wu J: Tracing and Characterizing the Development of Transplanted Female Germline Stem Cells In vivo. Mol Ther 2017;25:1408.

53 Sc SEM, Mari BEMD, Ph.D JMNMD, Ph.D CGTMD, Ph.D GKMD, Iris GPD, Reuven RPD, Ph.D BDMD: Snail, Slug, and Smad-interacting protein 1 as novel parameters of disease aggressiveness in metastatic ovarian and breast carcinoma. Cancer 2005;103:1631-1643.

54 Jin H, Yu Y, Zhang T, Zhou X, Zhou J, Jia L, Wu Y, Zhou BP, Feng Y: Snail is critical for tumor growth and metastasis of ovarian carcinoma. Int J Cancer 2010;126:2102-2111.

55 Hay ED: The mesenchymal cell, its role in the embryo, and the remarkable signaling mechanisms that create it. Dev Dynam 2005;233:706-720.

56 Mani SA, Guo W, Liao MJ, Eaton EN, Ayyanan A, Zhou AY, Brooks M, Reinhard F, Zhang CC, Shipitsin M: The epithelial-mesenchymal transition generates cells with properties of stem cells. Cell 2008; 133:704-715.

-57 Liu S, Sun J, Cai B, Xi X, Yang L, Zhang Z, Feng Y, Sun Y: NANOG regulates epithelial-mesenchymal transition and chemoresistance through activation of the STAT3 pathway in epithelial ovarian cancer. Tumour Biol 2016;37:1-10.

58 Li X, Yang J, Wang X, Li X, Liang J, Xing H: Role of TWIST2, E-cadherin and Vimentin in epithelial ovarian carcinogenesis and prognosis and their interaction in cancer progression. Eur J Gynaecol Oncol 2016; 37:100.

59 Cho KR, Shih IM: Ovarian Cancer. Annu Rev Pathol 2009;4:287.

60 Lee JM, Dedhar S, Kalluri R, Thompson EW: The epithelial-mesenchymal transition: new insights in signaling, development, and disease. J Cell Biol 2006;172:973-981.

61 Yoshida S, Furukawa N, Haruta S, Tanase Y, Kanayama S, Noguchi T, Sakata M, Yamada Y, Oi H, Kobayashi $\mathrm{H}$ : Expression profiles of genes involved in poor prognosis of epithelial ovarian carcinoma: a review. Int J Gynecol Cancer 2009;19:992-997.

62 Sabourin JC: [Epithelial ovarian cancer dysplasia: At last a "precancerous" lesion of the ovary!]. Ann Pathol 2011;31:2. 


\section{Cellular Physiology Cell Physiol Biochem 2018;50:214-232 \begin{tabular}{ll|l} 
DOI: 10.1159/000494001 & O 2018 The Author(s). Published by S. Karger AG, Basel \\
www.karger.com/cpb
\end{tabular} and Biochemistry}

Xu et al.: Mechanism for the Decision of OSESCs to Undergo Neo-Oogenesis or Ovarian

Tumorigenesis

63 Meryet-Figuière M, Lambert B, Gauduchon P, Vigneron N, Brotin E, Poulain L, Denoyelle C: An overview of long non-coding RNAs in ovarian cancers. Oncotarget 2016;7:44719.

-64 Zhou Y, Xu X, Lv H, Wen Q, Li J, Tan L, Li J, Sheng X: The Long Noncoding RNA MALAT-1 Is Highly Expressed in Ovarian Cancer and Induces Cell Growth and Migration. Plos One 2016;11:e0155250.

65 Vida C, Toda IMD, Cruces J, Garrido A, Gonzalez-Sanchez M, Fuente MDL: Role of macrophages in agerelated oxidative stress and lipofuscin accumulation in mice. Redox Biol 2017;12:423-437.

66 Rupaimoole R, Lee J, Haemmerle M, Ling H, Previs RA, Pradeep S, Wu SY, Ivan C, Ferracin M, Dennison JB: Long noncoding RNA ceruloplasmin promotes cancer growth by altering glycolysis. Cell Rep 2015;13: 2395-2402.

67 Sheng X, Li J, Yang L, Chen Z, Zhao Q, Tan L, Zhou Y, Li J: Promoter hypermethylation influences the suppressive role of maternally expressed 3, a long non-coding RNA, in the development of epithelial ovarian cancer. Oncol Rep 2014;32:277-285.

-68 Qiu JJ, Lin YY, Ye LC, Ding JX, Feng WW, Jin HY, Zhang Y, Li Q Hua KQ: Overexpression of long non-coding RNA HOTAIR predicts poor patient prognosis and promotes tumor metastasis in epithelial ovarian cancer. Gynecol Oncol 2014;134:121-128.

69 Cheng Z, Jing G, Li C, Ning L, Yang W, Qu X: A long noncoding RNA AB073614 promotes tumorigenesis and predicts poor prognosis in ovarian cancer. Oncotarget 2015;6:25381-25389.

70 Haider S, Meinhardt G, Velicky P, Otti GR, Whitley G, Fiala C, Pollheimer J, Knöfler M: Notch signaling plays a critical role in motility and differentiation of human first-trimester cytotrophoblasts. Endocrinology 2014;155:263-274.

71 Iso T, Kedes L, Hamamori Y: HES and HERP families: multiple effectors of the Notch signaling pathway. J Cell Physiol 2003;194:237-255.

-72 Jung SR, Song NJ, Yang DK, Cho YJ, Kim BJ, Hong JW, Yun UJ, Jo DG, Lee YM, Choi SY: Silk proteins stimulate osteoblast differentiation by suppressing the Notch signaling pathway in mesenchymal stem cells. Nutr Res 2013;33:162-170.

73 Piccin D, Yu F, Morshead CM: Notch signaling imparts and preserves neural stem characteristics in the adult brain. Stem Cells Dev 2013;22:1541.

74 You N, Liu W, Zhong X, Dou K, Tao K: Possibility of the enhanced progression of fetal liver stem/progenitor cells therapy for treating end-stage liver diseases by regulating the notch signaling pathway. Arch Med Res 2012;43:585.

75 Yu K, Spradling AC: Notch and Egfr signaling act antagonistically to regulate germ-line stem cell niche formation in Drosophila male embryonic gonads. Proc Natl Acad Sci USA 2010;107:14241.

76 Ward EJ, Shcherbata HR, Reynolds SH, Fischer KA, Hatfield SD, Ruoholabaker H: Stem Cells Signal to the Niche through the Notch Pathway in the Drosophila Ovary. Curr Biol 2006;16:2352-2358.

77 Zhang ZW, Men T, Feng RC, Li YC, Zhou D, Teng CB: miR-375 inhibits proliferation of mouse pancreatic progenitor cells by targeting YAP1. Cell Physiol Biochem 2013;32:1808-1817.

78 Zhao B, Lei QY, Guan KL: The Hippo-YAP pathway: new connections between regulation of organ size and cancer. Curr Opin Cell Biol 2008;20:638-646.

79 Lei QY, Zhang H, Zhao B, Zha ZY, Bai F, Pei XH, Zhao S, Xiong Y, Guan KL: TAZ Promotes Cell Proliferation and Epithelial-Mesenchymal Transition and Is Inhibited by the Hippo Pathway. Mol Cell Biol 2008; 28:24262436.

80 Polesello C, Tapon N: Salvador-warts-hippo signaling promotes Drosophila posterior follicle cell maturation downstream of notch. Curr Biol 2007;17:1864-1870.

-81 Barry ER, Camargo FD: The Hippo superhighway: signaling crossroads converging on the Hippo/Yap pathway in stem cells and development. Curr Opin Cell Biol 2013;25:247-253.

82 Karpowicz P, Perez J, Perrimon N: The Hippo tumor suppressor pathway regulates intestinal stem cell regeneration. Development 2010;137:4135.

83 Hao J, Zhang Y, Jing D, Li Y, Li J, Zhao Z: Role of Hippo signaling in cancer stem cells. J Cell Physiol 2014;229:266-270.

84 Hall CA, Wang R, Miao J, Oliva E, Shen X, Wheeler T, Hilsenbeck SG, Orsulic S, Goode S: Hippo pathway effector Yap is an ovarian cancer oncogene. Cancer Res 2010;70:8517-8525.

85 Zhang X, George J, Deb S, Degoutin JL, Takano EA, Fox SB, Bowtell DDL, Harvey KF: The Hippo pathway transcriptional co-activator, YAP, is an ovarian cancer oncogene. Oncogene 2011;30:2810. 


\section{Cellular Physiology Cell Physiol Biochem 2018;50:214-232 \begin{tabular}{c|c|c|} 
DOI: 10.1159/000494001 & O 2018 The Author(s). Published by S. Karger AG, Basel \\
www.karger.com/cpb
\end{tabular} and Biochemistry}

Xu et al.: Mechanism for the Decision of OSESCs to Undergo Neo-Oogenesis or Ovarian

Tumorigenesis

-86 Anand P, Kunnumakara AB, Sundaram C, Harikumar KB, Tharakan ST, Lai OS, Sung B, Aggarwal BB: Cancer is a Preventable Disease that Requires Major Lifestyle Changes. Pharm Res 2008;25:2097-2116.

87 Doll R, Peto R: The causes of cancer: quantitative estimates of avoidable risks of cancer in the United States today. J Natl Cancer Inst 1981;66:1191-1308.

-88 Calle EE, Rodriguez C, Walkerthurmond K, Thun MJ: Overweight, obesity, and mortality from cancer in a prospectively studied cohort of U.S. adults. N Engl J Med 2003;348:1625-1638.

-89 Belpomme D, Irigaray P, Hardell L, Clapp R, Montagnier L, Epstein S, Sasco AJ: The multitude and diversity of environmental carcinogens. Environ Res 2007;105:414.

$\$ 90$ Herbst AL: The epidemiology of ovarian carcinoma and the current status of tumor markers to detect disease. Am J Obstet Gynecol 1994;170:1105-1107.

-91 Cramer DW, Welch WR: Determinants of ovarian cancer risk. II. Inferences regarding pathogenesis. J Natl Canc Inst 1983; 71:717-721.

-92 Jr FJ, Grundy GW, Creagan ET, Everson RB: Six families prone to ovarian cancer. Cancer 2015;36:364-369.

-93 Greene MH, Clark JW, Blayney DW: The epidemiology of ovarian cancer. Semin Oncol 1984;11:209-226.

$\$ 94$ Dyck HG, Hamilton TC, Godwin AK, Lynch HAT, Maines-Bandiera SL, Auersperg N: Autonomy oft he epithelial phenotype in human ovarian surface epithelium: changes with neoplastic progression and with a family history of ovarian cancer. Int J Cancer 1996;69:429-436.

$\$ 95$ Fathalla MF: Incessant ovulation--a factor in ovarian neoplasia? Lancet 1971;2:163.

-96 Godwin AK, Testa JR, Handel LM, Liu Z, Vanderveer LA, Tracey PA, Hamilton TC: Spontaneous Transformation of Rat Ovarian Surface Epithelial Cells: Association With Cytogenetic Changes and Implications of Repeated Ovulation in the Etiology of Ovarian Cancer. J Natl Cancer Inst 1992;84:592-601.

$\$ 97$ Murdoch WJ, Mcdonnel AC: Roles of the ovarian surface epithelium in ovulation and carcinogenesis. Reproduction 2002;123:743-750.

$\$ 98$ Murphy ED, Beamer WG: Plasma gonadotropin levels during early stages of ovarian tumorigenesis in mice of the W x -W u genotype. Cancer Res 1973;33:721-723.

$\$ 99$ Danilovich N, Roy I, Sairam MR: Ovarian pathology and high incidence of sex cord tumors in follitropin receptor knockout (FORKO) mice. Endocrinology 2001;142:3673-3684.

100 Smith ER, Xu XX: Ovarian ageing, follicle depletion, and cancer: a hypothesis for the aetiology of epithelial ovarian cancer involving follicle depletion. Lancet Oncol 2008;9:1108-1111.

101 Stadel BV: Letter: The etiology and prevention of ovarian cancer. Am J Obstet Gyneco 1975;123:772-774.

102 Mertens-Walker I, Baxter RC, Marsh DJ: Gonadotropin signallin in epithelial ovarian cancer. Cancer Lett 2012;324:152-159.

103 Parte S, Bhartiya D, Telang J, Daithankar V, Salvi V, Zaveri K, Hinduja I: Detection, Characterization, and Spontaneous Differentiation In vitro of Very Small Embryonic-Like Putative Stem Cells in Adult Mammalian Ovary. Stem Cells Dev 2011;20:1451.

104 Parte S, Bhartiya D, Manjramkar DD, Chauhan A, Joshi A: Stimulation of ovarian stem cells by follicle stimulating hormone and basic fibroblast growth factor during cortical tissue culture. J Ovarian Res $2013 ; 6: 20$.

105 Parte S, Bhartiya D, Patel H, Daithankar V, Chauhan A, Zaveri K, Hinduja I: Dynamics associated with spontaneous differentiation of ovarian stem cells in vitro. J Ovarian Res 2014;7:25.

106 Patel H, Bhartiya D, Parte S, Gunjal P, Yedurkar S, Bhatt M: Follicle stimulating hormone modulates ovarian stem cells through alternately spliced receptor variant FSH-R3. J Ovarian Res 2013;6:52.

107 Deepa B, Kalpana S, Pranesh G, Harshada M: Gonadotropin treatment augments postnatal oogenesis and primordial follicle assembly in adult mouse ovaries? J Ovarian Res 2012;5:32.

108 Deepa B, Seema P, Hiren P, Kalpana S, Kusum Z, Indira H: Novel Action of FSH on Stem Cells in Adult Mammalian Ovary Induces Postnatal Oogenesis and Primordial Follicle Assembly. Stem Cells Int2015;2016:1-13.

109 Bhartiya D, Singh J: FSH-FSHR3-stem cells in ovary surface epithelium: basis for adult ovarian biology, failure, aging, and cancer. Reproduction 2015;149:35-48.

110 Baert T, Vergote I, An C: Ovarian cancer and the immune system. Gynecol Oncol Rep. 2017;19:57-58.

111 Song N, Li T, Zhang XM: Immune cells in tumor microenvironment. Prog Biochem Biophysics 2014;41: 1075-1084.

112 Cacan E: Epigenetic-mediated immune suppression of positive co-stimulatory molecules in chemoresistant ovarian cancer cells. Cell Biol Int 2017;41:328-339. 


\section{Cellular Physiology Cell Physiol Biochem 2018;50:214-232 \begin{tabular}{l|l|l}
\hline and Biochemistry 10.1159/000494001 & $\begin{array}{l}\text { C) } 2018 \text { The Author(s). Published by S. Karger AG, Basel } \\
\text { www.karger.com/cpb }\end{array}$
\end{tabular} and Biochemistry}

Xu et al.: Mechanism for the Decision of OSESCs to Undergo Neo-Oogenesis or Ovarian

Tumorigenesis

113 Karin M: Nuclear factor-kappaB in cancer development and progression. Nature 2006;441:431-436.

114 Mantovani A, Allavena P, Sica A, Balkwill F: Cancer-related inflammation. Nature 2008;454:436-444

115 Candido J, Hagemann T: Cancer-related inflammation. J Clin Immunol 2013;33 Suppl1:S79-84.

116 Aggarwal BB, Vijayalekshmi RV, Sung B: Targeting inflammatory pathways for prevention and therapy of cancer: short-term friend, long-term foe. Clin Cancer Res 2009;15:425-430.

117 Grivennikov SI, Greten FR, Karin M: Immunity, inflammation, and cancer. Cell 2010;140:883-899.

118 Gabrilovich DI, Ostrand-Rosenberg S, Bronte V: Coordinated regulation of myeloid cells by tumours. Nat Rev Immunol 2012;12:253-268.

119 Wynn TA, Chawla A, Pollard JW: Macrophage biology in development, homeostasis and disease. Nature 2013;496:445-455.

120 Franklin RA, Liao W, Sarkar A, Kim MV, Bivona MR, Liu K, Pamer EG, Li MO: The cellular and molecular origin of tumor-associated macrophages. Science 2014;344:921-925.

121 Kryczek I, Banerjee M, Cheng P, Vatan L, Szeliga W, Wei S, Huang E, Finlayson E, Simeone D, Welling TH: Phenotype, distribution, generation, and functional and clinical relevance of Th17 cells in the human tumor environments. Blood 2009;114:1141.

-122 Zhang L, Conejogarcia JR, Katsaros D, Gimotty PA, Massobrio M, Regnani G, Makrigiannakis A, Gray H, Schlienger K, Liebman MN: Intratumoral T cells, recurrence, and survival in epithelial ovarian cancer. $\mathrm{N}$ Engl J Med 2003;348:203-213.

123 Milne K, Köbel M, Kalloger SE, Barnes RO, Gao D, Gilks CB, Watson PH, Nelson BH: Systematic Analysis of Immune Infiltrates in High-Grade Serous Ovarian Cancer Reveals CD20, FoxP3 and TIA-1 as Positive Prognostic Factors. Plos One 2009;4:e6412.

124 Webb JR, Milne K, Watson P, Deleeuw RJ, Nelson BH: Tumor-infiltrating lymphocytes expressing the tissue resident memory marker CD103 are associated with increased survival in high-grade serous ovarian cancer. Clin Cancer Res 2014;20:434.

125 Bronger H, Singer J, Windmüller C, Reuning U, Zech D, Delbridge C, Dorn J, Kiechle M, Schmalfeldt B, Schmitt M: CXCL9 and CXCL10 predict survival and are regulated by cyclooxygenase inhibition in advanced serous ovarian cancer. Brit J Cancer 2016;115:553-563.

126 K KA, Peterson N, Truesdell P, Reid-Schachter G, Khalaj K, Ren R, Francis JA, Graham CH, Craig AW, Koti M: CXCL10 alters the tumour immune microenvironment and disease progression in a syngeneic murine model of high-grade serous ovarian cancer. Gynecol Oncol 2017;145:436-445.

127 Mitchem JB, Brennan DJ, Knolhoff BL, Belt BA, Zhu Y, Sanford DE, Belaygorod L, Carpenter D, Collins L, Piwnicaworms D: Targeting tumor-infiltrating macrophages decreases tumor-initiating cells, relieves immunosuppression, and improves chemotherapeutic responses. Cancer Res 2013;73:1128.

128 Joseph MM, Nair JB, Maiti KK, Sreelekha TT: Plasmonically Enhanced Galactoxyloglucan Endowed Gold Nanoparticles Exposed Tumor Targeting Biodistribution Envisaged in a Surface-Enhanced Raman Scattering Platform. Biomacromolecules 2017;18.

129 Vats K, Satpati D, Sharma R, Kumar C, Sarma HD, Banerjee S: Preparation and Comparative evaluation of 99m Tc-HYNIC-cNGR and 99m Tc-HYNIC-PEG2 -cNGR as Tumor Targeting Molecular Imaging Probes. J Labelled Compd Rad 2018;16:126-132.

130 Zhang RY, Wang ZY, Yang XQ Xuan Y, Cheng K, Li C, Song XL, An J, Hou XL, Zhao YD: Folic acid modified Pluronic F127 coating Ag2S quantum dot for photoacoustic imaging of tumor cell-targeting. Nanotechnology 2017;29.

131 Penn C, Yang K, Zong H, Lim JY, Cole A, Yang D, Baker J, Goonewardena SN, Buckanovich RJ: Therapeutic Impact of Nanoparticle Therapy Targeting Tumor Associate Macrophages. Mol Cancer Ther 2017;17:molcanther.0688.2017.

132 Schupp J, Krebs FK, Zimmer N, Trzeciak E, Schuppan D, Tuettenberg A: Targeting myeloid cells in the tumor sustaining microenvironment. Cell Immunol 2017.

133 Naz RK, Thurston D, Santoro N: Circulating tumor necrosis factor (TNF)-alpha in normally cycling women and patients with premature ovarian failure and polycystic ovaries. Am J Reprod Immunol 1995;34: 170175.

134 Singh N, Dadhwal V, Sharma KA, Mittal S: Xanthogranulomatous inflammation: a rare cause of premature ovarian failure. Arch Gynecol Obstet 2009;279:729-731. 


\section{Cellular Physiology Cell Physiol Biochem 2018:50:214-232 \begin{tabular}{ll|l} 
DOl: 10.1159/000494001 & $\begin{array}{l}\text { O } 2018 \text { The Author(s). Published by S. Karger AG, Basel } \\
\text { www.karger.com/cpb }\end{array}$ \\
\hline
\end{tabular} \\ $\mathrm{Xu}$ et al:: Mechanism for the Decision of OSESCs to Undergo Neo-Oogenesis or Ovarian Tumorigenesis}

135 Wang Y, Han L, Ou R, Yang N, Xie D, Chen Q: Analysis of anti-zona pellucida antibody and tumor necrosis factor- $\alpha, y$-interferon and interleukin- 2 in sera from patients with premature ovarian failure. Journal of Reproductive Medicine (China) 2003;12:47-50.

136 Sundaresan NR, Saxena VK, Sastry KV, Nagarajan K, Jain P, Singh R, Anish D, Ravindra PV, Saxena M, Ahmed KA: Cytokines and chemokines in postovulatory follicle regression of domestic chicken (Gallus gallus domesticus). Dev Comp Immunol 2008;32:253.

137 Said RS, El-Demerdash E, Nada AS, Kamal MM: Resveratrol inhibits inflammatory signaling implicated in ionizing radiation-induced premature ovarian failure through antagonistic crosstalk between silencing information regulator 1 (SIRT1) and poly(ADP-ribose) polymerase 1 (PARP-1). Biochem Pharmacol 2016; 103:140.

138 Lai D, Wang F, Dong Z, Zhang Q: Skin-derived mesenchymal stem cells help restore function to ovaries in a premature ovarian failure mouse model. Plos One 2014;9:e98749.

139 Bukovsky A: Immune maintenance of self in morphostasis of distinct tissues, tumour growth and regenerative medicine. Scand J Immunol 2011;73:159-189.

140 Bukovsky A: Cell Commitment by Asymmetric Division and Immune System Involvement. Prog Mol Subcell Biol 2007;45:179-204.

141 Bukovsky A, Caudle MR: Immunoregulation of follicular renewal, selection, POF, and menopause in vivo, vs. neo-oogenesis in vitro, POF and ovarian infertility treatment, and a clinical trial. Reprod Biol. Endocrinol 2012;10:97.

142 Kossowskatomaszczuk K, Geyter CD: Cells with Stem Cell Characteristics in Somatic Compartments of the Ovary. Biomed Res Int 2013;2013:310859. 